\section{To: (Receiving Organization) \\ Distribution \\ 5. Proj./Prog./Dept./Div.: \\ Privatization Infrastructure \\ 8. Originator Remarks: \\ for approval and release. \\ This replaces original EDT 618942 which was lost during routing for approvals. Engr.: R. J. Parazin}

11. Receiver Remarks: 11A. Design Basel ine Document? [] Yes [X] No
3. From: (Originating Organization) 4 4. Related EDT No.: Hanford-Fanks Intitiative Ruvatization Re NA

6. Design Authority/ Design Agent/Cog. 1 7. Purchase Order No.:

NA

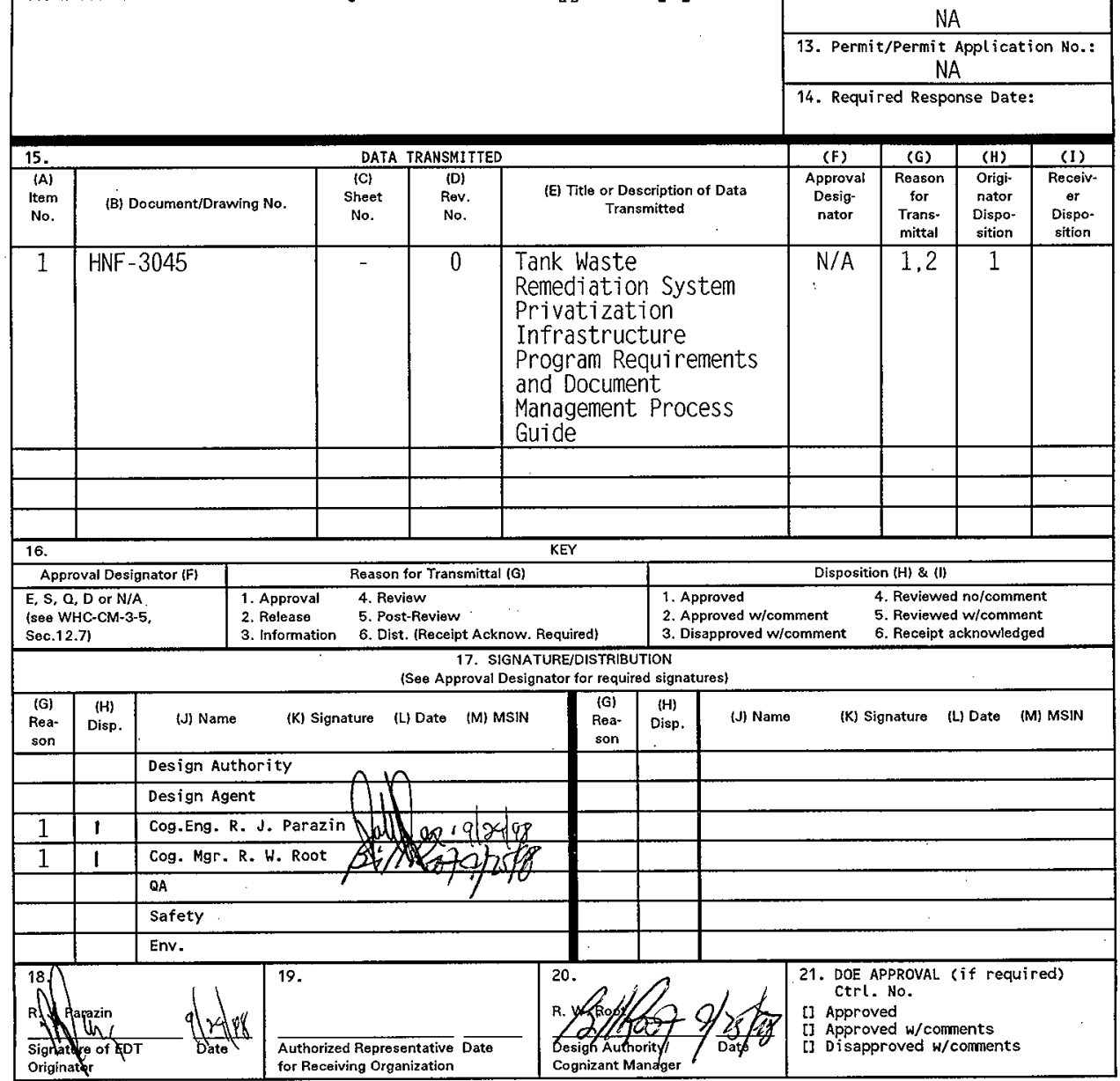




\section{Tank Waste Remediation System Privatization Infrastructure Program Requirements and Document Management Process Guide}

R. W. Root, R. J. Parazin (NHC), and H. Rossi (TRW)

Lockheed Martin Hanford Corporation

Richland, WA 99352

U.S. Department of Energy Contract DE-AC06-96RL13200

EDT/ECN: 625348

Org Code: 73500

UC: 721

B\&R Code: EW4010000

Total Pages: 55

Key Words: TWRS, configuration management

Abstract: This guide provides the Tank Waste Remediation system Privatization Infrastructure Program management with processes and requirements to appropriately control information and documents in accordance with the Tank Waste Remediation System Configuration Management Plan (Vann 1998b). This includes documents and information created by the program, as well as non-program generated materials submitted to the project. It provides appropriate approval/control, distribution and filing systems.

TRADEMARK DISCLAIMER. Reference herein to any specific commercial product, process, or service by trade name, trademark, manufacturer, or otherwise, does not necessarily constitute or imply its endorsement, recommendation, or favoring by the United States Government or any agency thereof or its contractors or subcontractors.

Printed in the United States of America. To obtain copies of this document, contact: Document Control Services, P.O. Box 950, Mailstop H6-08, Richland WA 99352, Phone (509) 372-2420; Fax (509) 376-4989.

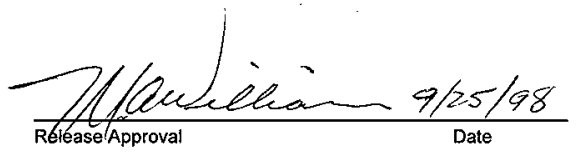

Approved For Public Release

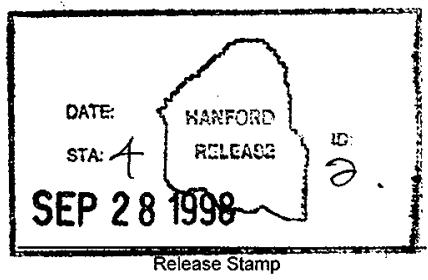

Release Stamp 


\title{
TANK WASTE REMEDIATION SYSTEM PRIVATIZATION INFRASTRUCTURE PROGRAM REQUIREMENTS AND DOCUMENT MANAGEMENT PROCESS GUIDE
}

July 1998

\author{
R. W. Root \\ Lockheed Martin Hanford Corporation \\ Richland, Washington
}

\section{R. J. Parazin}

Numatec Hanford Corporation

Richland, Washington

\section{H. Rossi}

TRW Environmental Systems

Richland, Washington

Prepared for

U.S. Department of Energy

Richland, Washington 
HNF-3045

Revision 0

This page intentionally left blank. 
HNF-3045

Revision 0

CONTENTS

1.0 PROCESS GUIDE PURPOSE $\ldots \ldots \ldots \ldots \ldots \ldots \ldots \ldots \ldots$

2.0 CONFIGURATION SYSTEM MANAGEMENT ELEMENT $\ldots \ldots \ldots \ldots \ldots \ldots$

3.0 INFRASTRUCTURE REQUIREMENTS DATABASE CHANGE

AND DOCUMENT CONTROL SYSTEMS $\ldots \ldots \ldots \ldots \ldots \ldots \ldots \ldots$

3.1 REQUIREMENTS DATABASE SYSTEM $\ldots \ldots \ldots \ldots \ldots \ldots \ldots$

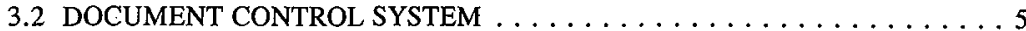

3.3 CONTROL OF SENSITIVE INFORMATION $\ldots \ldots \ldots \ldots \ldots \ldots \ldots 7$

3.4 REVIEW AND SIGN-OFF AUTHORITY $\ldots \ldots \ldots \ldots \ldots \ldots \ldots \ldots$

4.0 INFORMATION AND DOCUMENT CONTROL ASSESSMENTS $\ldots \ldots \ldots \ldots 9$

5.0 ROLES AND RESPONSIBILITIES $\ldots \ldots \ldots \ldots \ldots \ldots \ldots \ldots \ldots \ldots \ldots$

5.1 DOCUMENT AND CHANGE ORIGINATORS $\ldots \ldots \ldots \ldots \ldots \ldots \ldots$

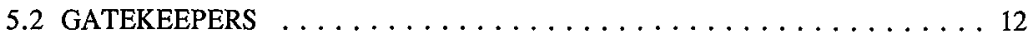

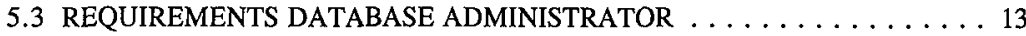

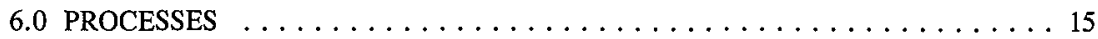

6.1 SUBMITTING DOCUMENTS RECEIVED FROM OUTSIDE $\ldots \ldots \ldots \ldots \ldots$

6.2 SUBMITTING REQUIREMENTS CHANGES $\ldots \ldots \ldots \ldots \ldots \ldots \ldots . \ldots 17$

6.3 CHANGING OR SUBMITTING INTERNALLY GENERATED

DOCUMENTS . . . . . . . . . . . . . . . . . . . . . 18

6.4 RETRIEVAL OF DOCUMENTS AND REVIEW OF UNPUBLISHED

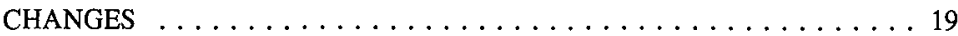

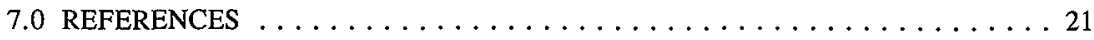

APPENDICES

A DOCUMENT CONTROL CHECKLIST $\ldots \ldots \ldots \ldots \ldots \ldots \ldots$ A-1

B SAMPLE PROJECT RECORDS INDEX $\ldots \ldots \ldots \ldots \ldots \ldots$ B-1

C TANK WASTE REMEDIATION SYSTEM PRIVATIZATION

INFRASTRUCTURE REQUIREMENTS DATABASE

CHANGE REQUEST FORM $\ldots \ldots \ldots \ldots \ldots \ldots \ldots \ldots \ldots \ldots$. 1

D SENSITIVE INFORMATION CONTROL INSTRUCTIONS AND

FORMS $\ldots \ldots \ldots \ldots \ldots \ldots \ldots \ldots \ldots \ldots \ldots \ldots \ldots \ldots \ldots \ldots \ldots \ldots \ldots$ 
HNF-3045

Revision 0

\section{LIST OF FIGURES}

1. Document and Electronic File Control Flow $\ldots \ldots \ldots \ldots \ldots \ldots \ldots$

2. Information and Documentation Management Flow $\ldots \ldots \ldots \ldots \ldots \ldots$

\section{LIST OF TABLES}

1. Roles and Responsibilities Matrix $\ldots \ldots \ldots \ldots \ldots \ldots \ldots \ldots \ldots$

2. Submitting Documents Received From Outside Infrastructure. . . . . . . . . . 16

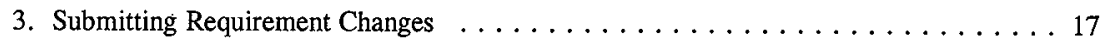

4. Changing or Submitting Documents Generated by the Tank Waste Remediation System Infrastructure Program $\ldots \ldots \ldots \ldots \ldots$ 
HNF-3045

Revision 0

\section{LIST OF TERMS}

$\begin{array}{ll}\text { CM } & \text { Configuration Management } \\ \text { CMP } & \text { Configuration Management Plan } \\ \text { DCS } & \text { Document Control System } \\ \text { DCSC } & \text { Document Control Service Center } \\ \text { DOE } & \text { U.S. Department of Energy } \\ \text { F\&R } & \text { Functions and requirements } \\ \text { GK } & \text { Gatekeeper } \\ \text { HLAN } & \text { Hanford Local Area Network } \\ \text { PFC } & \text { Project File Custodian } \\ \text { PHMC } & \text { Project Hanford Management Contractor } \\ \text { RDA } & \text { Requirements Database Administrator } \\ \text { RDD-100 } & \text { Requirements Driven Design-100 (database) } \\ \text { RMIS } & \text { Records Management Information System } \\ \text { ROR } & \text { Record of Revision } \\ \text { TWRS } & \text { Tank Waste Remediation System } \\ \text { WFC } & \text { Working File Custodian }\end{array}$


HNF-3045

Revision 0

This page intentionally left blank. 
HNF-3045

Revision 0

\author{
TANK WASTE REMEDIATION SYSTEM \\ PRIVATIZATION INFRASTRUCTURE PROGRAM \\ REQUIREMENTS AND DOCUMENT \\ MANAGEMENT PROCESS GUIDE
}

\title{
1.0 PROCESS GUIDE PURPOSE
}

This guide provides the Tank Waste Remediation System (TWRS) Privatization Infrastructure Program management with processes and requirements to appropriately control information and documents in accordance with the Tank Waste Remediation System Configuration Management Plan (CMP) (Vann 1998b). This includes documents and information created by the program, as well as non-program generated materials submitted to the project. It is intended to provide program team members with simple instructions for getting information into the appropriate approval, control, distribution and filing systems. The TWRS Privatization Infrastructure Program, which includes Project W-519, is referred to as Infrastructure throughout this document. Document control processes for both the Infrastructure Program and Project W-519 should be a consolidated effort to eliminate the redundancy of resource requirements.

The attached Document Control Checksheet (Appendix A) should be used as a template for processing and tracking database changes and documents. The checksheet is offered as an "optional aid," and is not to be retained in the permanent files. As an optional aid, users should use a graded approach to determine the level of its usage.

The change and document control processes described herein provide project management with visibility into, and control over, changes that affect the project. These systems also provide a controlled, centralized, shared access to accurate, consistent, and timely information for all Infrastructure participants. This access will facilitate the coordination of efforts for the efficient execution of the project mission. The systems also provide a change history and traceability to source documents and to decision making logic, and further provide measures for controlling and protecting sensitive information. The described processes meet all relevant configuration management (CM), systems engineering, and Hanford Site document control and recordkeeping requirements.

As a project under the Tank Waste Retrieval (TWR) and Disposal/TWRS programs, Infrastructure is subject to the requirements of the TWRS CMP (Vann 1998b), and the TWRS Configuration Management Implementation Plan (Vann 1997), which comply with the configuration management requirements defined in the Configuration Management Plan (FDH 1997), TWRS Systems Engineering Management Plan (Peck 1998), Tank Waste Remediation System Program Plan (Freeman 1988), and ultimately the U.S. Department of Energy (DOE) Guide for Operational Configuration Management Programs Including the 
HNF-3045

Revision 0

Adjunct Programs of Design Reconstitution and Material Conditioning and Aging Management (DOE 1993).

The TWRS CMP (Vann 1998b) integrates technical and administrative control to establish and maintain consistency among requirements, product configuration, and product information during all phases of the product's life cycle. Information and document control requirements established by the TWRS CMP (Vann 1998b) must be specified in vendor and subcontractor statements of work to assure information received is in a useable format and comply with deliverable requirements.

Configuration Management includes the following:

- CM System Management

- Configuration Item and Configuration Information Identification

- Configuration Status Accounting

- Change Control

- CM Assessment

- Design Requirements Control

- Document and Information Control.

This document provides detailed guidance for Design Requirements Control and Document Control, and provides references to applicable guidance to the remaining elements. Copies of all materials referenced in this document are retained in the Infrastructure working file (See Section 3.2). 
HNF-3045

Revision 0

\subsection{CONFIGURATION SYSTEM MANAGEMENT ELEMENT}

The Configuration System Management element establishes oversight for CM and provides for $\mathrm{CM}$ integration of participants to ensure the integrity and quality of the baseline, processes, and implementing procedures. It includes the following:

- Program Planning

- CM Training

- Vendor and Contractor Control

- Interfaces

- Procedures.

See the Tank Waste Remediation System Configuration Management Program Plan (Vann 1998a) and the Tank Waste Remediation System Configuration Management Implementation Plan (Vann 1997) for a more detailed description and specific directions.

\subsection{INFRASTRUCTURE REQUIREMENTS DATABASE CHANGE AND DOCUMENT CONTROL SYSTEMS}

The requirements database change and document control functions are separate, but linked, systems. The requirements database system manages Infrastructure design requirements using an automated database. The document control system (DCS) manages all Infrastructure generated and received records, documents and files, including those produced by the requirements database system, using existing Hanford site document control resources. This includes both hard copy and electronic files generated internally and received from external sources, such as vendors. Vendor files include a wide variety of media, such as zip drives, photo CDs, etc. The DCS further includes processes for controlling and protecting sensitive information.

Some documents used by the Infrastructure may come from and are controlled by other Hanford programs, projects, operations, etc. In cases where the documents are controlled outside of the Infrastructure organization, pointers to these other systems should be included in the system without duplicating records. This may be done by entering a memo referencing such documents and indicating their sources. For changes to the technical scope of work, cost, and schedule baselines, related to the Change Control Process, see Hanford Site standard Management Control System (FDH 1996), Baseline Change Control (FDH 1997c), and TWRS Change Control (Rosenberry 1997). This control manual provides a step-by-step instruction for formal change control. 
HNF-3045

Revision 0

\subsection{REQUIREMENTS DATABASE SYSTEM}

The Requirements Driven Design-100 (RDD-100) database is the computer software tool used for controlling requirements related data changes. It contains baselined information, including the following:

- Functions and Performance Specifications

- Interface Requirements

- Design Constraints

- Function and Flow Block Diagrams

- Architectural Descriptions

- Requirements Related Issues

- Requirement Related Decisions.

As an approved baseline, the RDD-100 files are subject to all $\mathrm{CM}$ change control requirements, as described in Management Control System (FDH 1996), and TWRS CMP (Vann 1998b).

In addition to controlling baselined requirements files, the RDD-100 system also serves as a tool to support requirements related processes. By providing "working copies" of baselined files, the system allows data to be used, under the auspices of the appropriate gatekeeeper, without breaching the configuration control of baselined files. The database system can therefore be used to develop database change requests, as well as for the preparation of documents, as listed below. All documents generated for the RDD-100 system are subject to $\mathrm{CM}$.

- Specifications

- Functions \& Requirements (F\&R) Documents:

- F\&R Allocation Sheets

- Design Constraint Forms.

- Interface Control Descriptions

- Issues Lists

- Other Custom Reports and Documents.

Infrastructure Program technical leads and subject matter experts serve as Gatekeepers for submitting data into the Requirements Database, for their respective areas of responsibility (see Section 5.0, Table 1, for a list of Gatekeepers). The Gatekeepers review, revise, and/or approve all changes to the database, and submit them to the database administrator for entry, as described in Section 5.2 of this guide. Once entered into the database, the requirements system processes, stores, and formats changes for incorporation into printed documents and/or for viewing using the RDD-100 Browser. All changes to the baselined database must follow 
all rules and requirements for change control, using appropriate forms (Engineering Change Notice [ECN], Engineering Data Transmittal [EDT], etc.), as prescribed by the Tank Waste Remediation System Configuration Management Program Plan (Vann 1998a).

Not all changes require the generation and/or distribution of revised requirements documents. The administrator of the requirements database normally compiles minor changes until the document owner and/or Gatekeeper decides to issue a revised document to meet milestones and other deliverable requirements. To revise documents, the database system incorporates accumulated changes and produces a document for delivery to the document owner or Gatekeeper. Document Ownets/Gatekeepers are then responsible for entering the document into the Infrastructure DCS, as described in Sections 5.1, 5.4, and 5.5.

\subsection{DOCUMENT CONTROL SYSTEM}

The DCS performs the control function for configuration management controlled documents and also serves as an information management service for records and files. It is intended to collect, distribute, store, and control all documents and communications generated and/or received in support of the Infrastructure project, as shown in Figure 1. This includes all letters, study reports, action item lists, business sensitive information, authorizations, telephone communication notes, etc., produced within the project, as well as materials submitted to the project from outside sources. Appendix B provides a sampling of typical indexing subjects used by DCS for organizing project files, and is included as a reference as to the types of information subject to the DCS.

Infrastructure's electronic files are structured to parallel the DCS hard file list as shown in Appendix B, and are stored in the Records Management Information System (RMIS) project and individual working file levels. These electronic files are stored on a shared drive designated for the Project W-519 and are automatically backed up nightly. Higher-level files will be password protected and available to participants as read only. File custodians, as described in Section 5.0, have a read-write capability on these directories. Electronic media to be stored and controlled include photo-CDs, zip drives, videos, as well as more conventional shared drive access to document files. It should be noted that business sensitive information is not scanned into the electronic system, except as titles indexed for tracking. See Section 3.3 of this document for a more detailed discussion of sensitive information.

The document control function of the DCS ensures that controlled documents are properly prepared, reviewed, approved, distributed, revised and retained as completed records. DSC record management ensures that completed record copies of documents are generated, protected, identified, dispositioned, stored, and retained in a readily retrievable manner, in accordance with federal requirements. 
HNF-3045

Revision 0

Figure 1. Document and Electronic File Control Flow.

Originators' Documonts* and Electronic Files working File

(WFC)
Project Filo

Custodian (PFC)

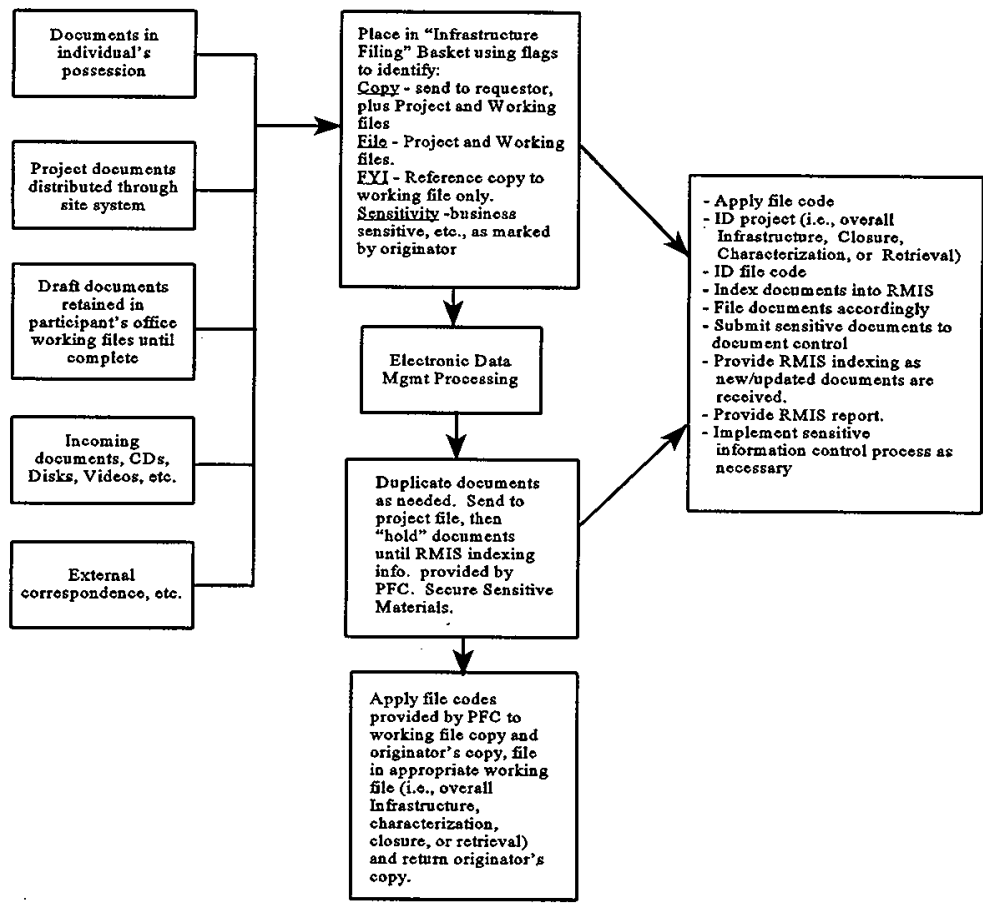

- With Gatekeeper Concurrence

PFC - Project Filo Custodian

RMIS - Record Management Information System

WFC - Working File Custodian 
The Infrastructure project uses existing Hanford documentation and records management resources for document control. The Lockheed Martin Services Inc., Documentation and Records Management group, provides site-wide information management and document control services. These services include the operation of localized Document Control Service Centers (DCSC) that process incoming documents and maintain Infrastructure project files. The services provided by the centers include document scanning, indexing, document release, document clearance, distribution, and storage, as required. The DCSC, currently located in 2440 Stevens, Room 1310, serves as the TWRS Document/Information Management Center, and houses the Infrastructure Project File. It is supported by an assigned Infrastructure Project File Custodian (PFC) located in Room 1310. A listing of other DCSC locations is available on the HLAN (Hanford Information), under "Document Service Centers."

In addition to the project files maintained by Documentation and Records Management, a duplicate set of files will be maintained and controlled as working files in the Project Office, for use by Infrastructure personnel. These files will be maintained by a Working File Custodian (WFC) located in the Project Office.

\subsection{CONTROL OF SENSITIVE INFORMATION}

All Infrastructure personnel are responsible for controlling sensitive information in their possession. This includes contractor proprietary, business sensitive, competition sensitive, etc. documents, records, and data. Appropriate actions must be taken by the holder to provide locked storage of such materials and to prevent their inadvertent improper release. Documents and information determined to be sensitive must be identified and marked by the Infrastructure originator or receiver, and verified appropriate by the gatekeeper. Once identified and processed by the originator (See Sections 5.0 and 6.0), sensitive materials must be passed directly to the appropriate file custodian for further processing into the DCS. See Appendix D for a detailed description of the sensitive information types, their processing, processing of documents for release, and sample forms.

\subsection{REVIEW AND SIGN-OFF AUTHORITY}

Changes that affect the technical or performance baseline (Class I Changes), require dispositioning by the Project Hanford Management Contractor (PHMC) Change Board and the RL TWRS Director. Changes that effect the scope, schedule, and/or budget at the cost account level of the project (Class II Changes) require PHMC Change Control Board approval. For such changes, see the Management Control System (FDH 1996), Baseline Change Control (FDH 1997c), TWRS Change Control (Rosenberry 1997), and the Tank Waste Remediation System Configuration Management Program Plan (Vann 1998a).

Other changes that do not affect baseline cost, scope, or schedule (Class III Changes) require dispositioning by the Project Manager for verification of implementation. The Infrastructure Program Office is responsible for configuration management of the project's 


\section{HNF-3045}

\section{Revision 0}

baseline documents. All changes must be approved by the Infrastructure Project Manager and the technical leads, or gatekeepers, for the Demonstrate Retrieval Technologies In-Tank, Establish Closure Basis and Implement Closure subprojects. See Table 1 for a listing of Gatekeepers.

Changes are submitted to the cognizant technical lead for initial review and approval. They are then either implemented or submitted directly to the Project Manager, as determined by the Gatekeeper (technical lead). 
HNF-3045

Revision 0

\subsection{INFORMATION AND DOCUMENT CONTROL ASSESSMENTS}

The assessment element of CM defines facility configuration management needs, and measures the effectiveness of the CM program in establishing and maintaining the program's basic relationships, throughout the life of the facility: As described in the Guide to

Operational Configuration Management (DOE 1993), the assessment includes the following:

- Programmatic Assessments:

- Initial Assessments

- Post-implementation Assessments

- Periodic Effectiveness Assessments

- Vendor and Contractor Assessments

- Technical Reviews, Audits and Assessments

- Physical Configuration Assessments

- Periodic Equipment Performance Monitoring

- Post-Modification Testing.

See Tank Waste Remediation System Configuration Management Program Plan (Vann 1998a) and Tank Waste Remediation System Configuration Management Program Implementation Plan (Vann 1997) for specific directions. 
HNF-3045

Revision 0

This page intentionally left blank. 
HNF-3045

Revision 0

\subsection{ROLES AND RESPONSIBILITIES}

The following Sections (5.1-5.6) provide a top level description of the information and documentation control roles of participants. See Section 6.0 for detailed instructions and examples. The following matrix (Table 1) is a directory of Infrastructure performers, provided to facilitate processing.

Table 1. Roles and Responsibilities Matrix.

\begin{tabular}{|l|l|l|l|}
\hline \multicolumn{1}{|c|}{ Role } & \multicolumn{1}{|c|}{ Name } & \multicolumn{1}{c|}{ Title } & \multicolumn{1}{c|}{ Area of concern } \\
\hline \multirow{4}{*}{ Gatekeepers: } & Bill Root & $\begin{array}{l}\text { Program } \\
\text { Manager }\end{array}$ & W-519 Program Management \\
\cline { 2 - 4 } & Bob Parazin & $\begin{array}{l}\text { Project } \\
\text { Manager }\end{array}$ & Infrastructure (W-519) Project \\
\cline { 2 - 4 } & Gary Porter & $\begin{array}{l}\text { Project } \\
\text { Engineer }\end{array}$ & $\begin{array}{l}\text { Utilities Systems (Non- } \\
\text { electrical Systems) }\end{array}$ \\
\cline { 2 - 5 } & $\begin{array}{l}\text { Gurdian Singh } \\
\text { (W-519) }\end{array}$ & $\begin{array}{l}\text { Project } \\
\text { Engineer }\end{array}$ & $\begin{array}{l}\text { Utilities Systems (Electrical } \\
\text { Systems) }\end{array}$ \\
\cline { 2 - 5 } & Dave Fort (W-519) & $\begin{array}{l}\text { Technical } \\
\text { Support }\end{array}$ & Utilities Systems \\
\cline { 2 - 5 } & Jeff Huston & $\begin{array}{l}\text { Subject Matter } \\
\text { Expert }\end{array}$ & Quality Assurance \\
\hline $\begin{array}{l}\text { W-519 Project } \\
\text { Files Custodian }\end{array}$ & Barry Martin & $\begin{array}{l}\text { Records } \\
\text { Specialist }\end{array}$ & $\begin{array}{l}\text { Document Control Service } \\
\text { Center }\end{array}$ \\
\hline $\begin{array}{l}\text { W-519 Work } \\
\text { Files Custodian }\end{array}$ & Marge Petty & Secretary & W-519 Support \\
\hline $\begin{array}{l}\text { Requirements } \\
\text { Database } \\
\text { Administrator }\end{array}$ & $\begin{array}{l}\text { Ron Barden (TRW } \\
\text { Environmental } \\
\text { Systems) }\end{array}$ & $\begin{array}{l}\text { Project } \\
\text { Engineer }\end{array}$ & Requirements Database \\
\hline
\end{tabular}


HNF-3045

Revision 0

\subsection{DOCUMENT AND CHANGE ORIGINATORS}

Document and change originators perform the following tasks:

- Develop changes, original documents, drawings, records, electronic files etc., or receive documents, CDs, videos, disks, etc., from outside Infrastructure.

- Verify through the DCSC that materials, files, etc., are on an acceptable media per site electronic records standard.

- Prepare justification notices and explanations as required.

- Prepare necessary cover pages and forms.

- Prepare distribution lists, to include Infrastructure PFC and WFC.

- Obtain required signatures and authorizations, through the cognizant Gatekeeper(s).

- Submit approved document or change package, including document and necessary forms, into the appropriate system:

- Requirements Database, through Gatekeepers, for requirements and specification changes

- DCS for new, changed, or received documents and records, with gatekeeper approval.

- Implement process for the control of sensitive information through the Infrastructure PFC.

\subsection{GATEKEEPERS}

Gatekeepers have responsibility for the following:

- Review changes, original documents, etc. for correctness, concurrence and approval for entry into the system, etc.

- Comment on, or correct, submittals, as necessary.

- Provide change authorization by signature, or through Infrastructure Project Manager, etc.

- Submit the database change packages to the Requirements Database Administrator (RDA). 
HNF-3045

Revision 0

- Return completed/approved documents to originator for processing through DCSC, or submit documents prepared by the RDA to DCSC directly.

- Review documents for impact on the requirements database, and channel information into database as necessary.

- Identify sensitive information and ensure control process is implemented through the originator (described above).

\subsection{REQUIREMENTS DATABASE ADMINISTRATOR}

The RDA is responsible for the following:

- Review changes for adherence to data structure rules.

- Sign-off on Database Change Request, prior to data entry.

- Input authorized changes into the RDD-100 database.

- Maintain Browser and its files.

- Prepare necessary or requested documents for signature and distribution.

- Return completed documents to the Gatekeeper for processing by DCS.

\subsection{DOCUMENT CONTROL SERVICE CENTERS}

The Document Control Service Centers (DCSC) perform the following:

- Process document packages, which include the subject document and required forms, etc., as necessary, according to the Document Control Manual (FDH 1997b).

- Distribute released documents per the distribution list provided (to include Infrastructure PFC and WFC).

- Control access to sensitive information.

- Provide access to electronic files, as authorized.

- Provide hard copies of documents as requested and authorized.

\subsection{INFRASTRUCTURE PROGRAM FILE CUSTODIAN}

The PFC is responsible for the following: 
HNF-3045

Revision 0

- Sort and file inputs by subproject

- Process Electronic Files

- Maintain files

- Set file names and locations

- Control access to files

- Ensure password protection

- Index files

- Enter electronic file to shared drive

- Provide copies as requested

- Maintain/update designated files on Infrastructure shared drive.

- Control access to sensitive information.

\subsection{INFRASTRUCTURE WORKING FILE CUSTODIAN}

The WFC is responsible for the following:

- Receive documents, etc., from originators, sort and process by subproject.

- Submit documents, etc., to PFC for processing.

- Maintain updated working files in Project office.

- Control access to working files.

- Verify electronic documents match hard copy of documents.

- Provide copies as requested.

- Maintain controlled copies of all documents referenced in the desk instruction.

- Control access to sensitive information. 
HNF-3045

Revision 0

\subsection{PROCESSES}

The following processes are designed to facilitate the flow of data, documents and records from their originators, through appropriate approval cycles, and into working and project files. Figure 2 provides an overview of the processes to guide users to the appropriate process to meet their needs.

Figure 2. Information and Documentation Management Flow.

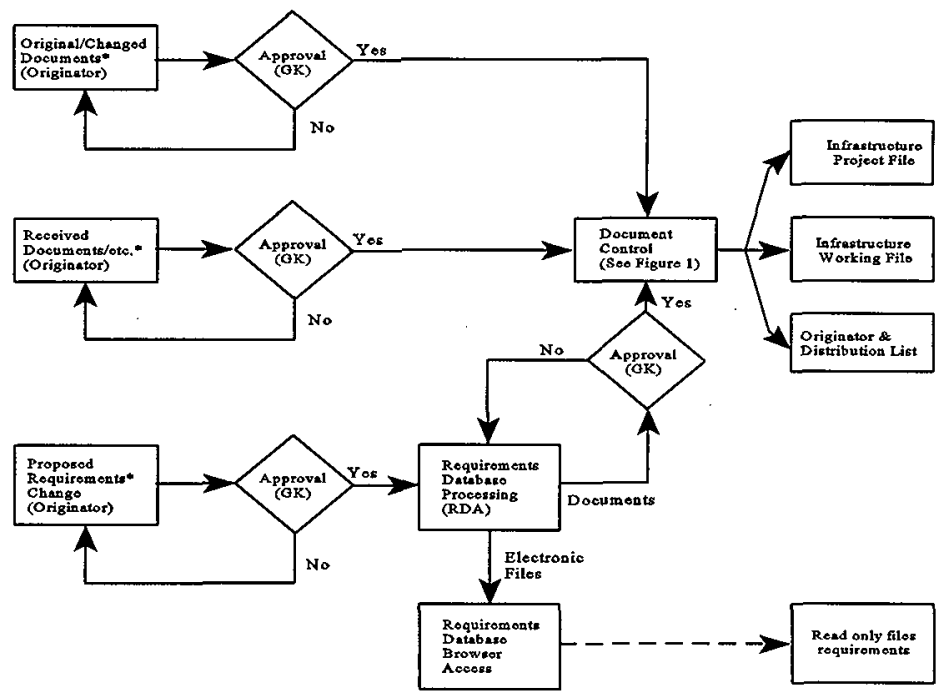

* Completed packages to includo all forms (ECN, EDT, oto.) and a document

identification number, as issued by the Document Control Service Center.

GK - Gatekeeper

RDA = Requirements Databose Administretor

WFC $=$ Working Pile Custodian 
All documents, data, and information relevant to the Infrastructure Program should eventually end up in the permanent project file, the Infrastructure working file, and in the electronic file system maintained by DCS. They are processed through the gatekeepers for review and approval, and then to WFC for entry into the DCS.

\subsection{SUBMITTING DOCUMENTS RECEIVED FROM OUTSIDE}

The process for submitting documents received from outside Infrastructure is shown in Table 2.

Table 2. Submitting Documents Received From Outside Infrastructure.

\begin{tabular}{|c|c|l|}
\hline Step & \multicolumn{1}{|c|}{ By } & \multicolumn{1}{|c|}{ Process } \\
\hline A & Originator & $\begin{array}{l}\text { Prepare brief informal cover memo of explanation, including } \\
\text { sensitivities, and necessary forms (ECN, EDT, etc.). }\end{array}$ \\
\hline B & Originator & Submit to cognizant Gatekeeper. \\
\hline C & Gatekeeper & $\begin{array}{l}\text { Review and approve for permanent filing in the Document Control } \\
\text { System. Ensure sensitive materials are protected (see Section 3.4). }\end{array}$ \\
\hline D & Gatekeeper & Review for impact on requirements database, baselines, etc. \\
\hline E & Gatekeeper & Return to originator. \\
\hline F & Originator & $\begin{array}{l}\text { Submit to Working File Custodian, with flags identifying distribution } \\
\text { and sensitivity. }\end{array}$ \\
\hline G & WFC & Process (See Figure 1, Document and Electronic File Control Flow). \\
\hline
\end{tabular}

$\mathrm{ECN}=$ Engineering Change Notice

EDT $=$ Engineering Data Transmittal

WFC $=$ Working File Custodian. 
HNF-3045

Revision 0

\subsection{SUBMITTING REQUIREMENTS CHANGES}

The process for submitting requirements changes is shown in Table 3.

Table 3. Submitting Requirement Changes.

\begin{tabular}{|c|c|c|}
\hline Step & By & Process \\
\hline A & Originator & $\begin{array}{l}\text { Prepare necessary Requirements Database Change Request (See } \\
\text { Appendix C). }\end{array}$ \\
\hline B & Originator & $\begin{array}{l}\text { Submit requirements change package to Gatekeeper, including } \\
\text { necessary forms (ECN, EDT, etc.). }\end{array}$ \\
\hline $\mathrm{C}$ & Gatekeeper & $\begin{array}{l}\text { Review/revise, approve/sign-off or consult with other Gatekeepers } \\
\text { and/or Project Manager for approval/sign-off. }\end{array}$ \\
\hline $\mathrm{D}$ & Gatekeeper & Submit to Requirements Database Administrator. \\
\hline $\mathrm{E}$ & RDA & $\begin{array}{l}\text { Review for proper database structure, revise/consult with originator } \\
\text { and approve for data entry. }\end{array}$ \\
\hline F & RDA & $\begin{array}{l}\text { Process changes/prepare Requirements Driven Design-100 (database) } \\
\text { generated documents if requested. }\end{array}$ \\
\hline G & RDA & $\begin{array}{l}\text { Return Requirements Driven Design-100 (database) documents to } \\
\text { Gatekeeper, if generated. }\end{array}$ \\
\hline $\mathrm{H}$ & Gatekeeper & $\begin{array}{l}\text { Return Requirements Driven Design-100 (database) document with } \\
\text { authorizing signature(s) to originator or owner. }\end{array}$ \\
\hline I & Originator & Obtain other approval signatures, if required. \\
\hline $\mathrm{J}$ & Originator & Deliver to WFC for processing. \\
\hline $\mathrm{K}$ & WFC & $\begin{array}{l}\text { Begin Document Control System Processing (See Figure 1, Document } \\
\text { and Electronic File Control Flow). }\end{array}$ \\
\hline
\end{tabular}

$\mathrm{ECN}=$ Engineering Change Notice

$\mathrm{EDT}=$ Engineering Data Transmittal

RDA $=$ Requirements Database Administrator

WFC $=$ Working File Custodian. 
HNF-3045

Revision 0

\subsection{CHANGING OR SUBMTTTING INTERNALLY GENERATED DOCUMENTS}

The process for changing or submitting documents generated by the Infrastructure is shown in Table 4 :

Table 4. Changing or Submitting Documents Generated by the Tank Waste Remediation System Infrastructure Program.

\begin{tabular}{|c|c|c|}
\hline Step & By & Process \\
\hline A & Originator & $\begin{array}{l}\text { Request Document Identification Number for Rev. } 0 \text { documents from } \\
\text { the Document Control Service Center. }\end{array}$ \\
\hline B & Originator & $\begin{array}{l}\text { Prepare necessary cover sheets and forms. } \\
\text { - } \quad \text { Cover sheet (macro GEF321) } \\
\text { - } \quad \text { Engineering Data Transmittal (Form BD-7400-172-2 [macro } \\
\text { GEF097]) for all Rev. 0 documents and drawings. } \\
\text { - } \quad \text { Distribution list (macro WEF067), to include the Working File } \\
\text { and Project File Custodians. } \\
\text { - Engineering Change Notice (macros GEF095, GEF096) for all } \\
\text { revisions after Rev. 0. } \\
\text { - Record of Revision (ROR) (macro WEF168) for all revisions } \\
\text { after Rev. 0. } \\
\text { - Note sensitive materials if necessary. }\end{array}$ \\
\hline $\mathrm{C}$ & Originator & Submit to Gatekeeper for review/comment (see Section 3.4). \\
\hline $\mathrm{D}$ & Gatekeeper & $\begin{array}{l}\text { Review/revise, approve/sign-off or submit to Program Manager for } \\
\text { approval/sign-off, or for upper level and approval, if necessary. }\end{array}$ \\
\hline E & Gatekeeper & $\begin{array}{l}\text { Review for impact on requirements database, and ensure sensitive } \\
\text { materials are protected. }\end{array}$ \\
\hline $\mathrm{F}$ & Gatekeeper & Return document with authorizing signature(s) to originator. \\
\hline G & Originator & Deliver to WFC for processing. \\
\hline $\mathrm{H}$ & WFC & $\begin{array}{l}\text { Begin Document Control System Processing (See Figure 1, Document } \\
\text { and Electronic File Control Flow). }\end{array}$ \\
\hline $\mathbf{I}$ & WFC & $\begin{array}{l}\text { Compare electronic copies against hard copy original for accuracy, } \\
\text { after distribution, etc., and file. }\end{array}$ \\
\hline
\end{tabular}

WFC $=$ Working File Custodian 
HNF-3045

Revision 0

\subsection{RETRIEVAL OF DOCUMENTS AND REVIEW OF UNPUBLISHED CHANGES}

Contact the PFC or WFC to obtain or view released documents, etc., and for access to electronic file. Contact the RDA for access to the database browser to review all unpublished changes to the requirements database. 
HNF-3045

Revision 0

This page intentionally left blank. 
HNF-3045

Revision 0

\subsection{REFERENCES}

DOE, 1993, Guide for Operational Configuration Management Programs, Including the Adjunct Programs of Design Reconciliation and Material Conditioning and Aging Management, U.S. Department of Energy, Richland, Washington.

FDH, 1996, Management Control System, HNF-0842, Fluor Daniel Hanford, Inc., Richland, Washington.

FDH, 1997a, Configuration Management Plan, HNF-MP-013, Rev. 0, Fluor Daniel Hanford Inc., Richland, Washington.

FDH, 1997b, Document Control Manual, HNF-PRO-224, Fluor Daniel Hanford, Inc., Richland, Washington.

FDH, 1997c, Baseline Change Control, HNF-PRO-569, Fluor Daniel Hanford, Inc., Richland, Washington.

Freeman, D.V., 1998, Tank Waste Remediation System Program Plan, HNF-1883, Rev. 0, prepared by Lockheed Martin Hanford Corporation for Fluor Daniel Hanford Inc., Richland, Washington.

Peck, L.G., 1998, Tank Waste Remediation System Systems Engineering Management Plan, HNF-SD-WM-SEMP-002, Rev. 1, prepared by Lockheed Martin Hanford Corporation for Fluor Daniel Hanford Inc., Richland, Washington.

Rosenberry, M. W., 1997, TWRS Change Control, LMH-MD-004, Rev. 0, Lockheed Martin Hanford Corporation, Richland, Washington.

Vann, J. M., 1997, Tank Waste Remediation System Configuration Management Implementation Plan, HNF-SD-WM-CM-014, Rev. 1, Lockheed Martin Hanford Corporation, Richland, Washington.

Vann, J. M., 1998a, Tank Waste Remediation System Configuration Management Program Plan, HNF-SD-WM-CM-013, Rev. 0, Westinghouse Hanford Company, Richland, Washington.

Vann, J. M., 1998b, Tank Waste Remediation System Configuration Management Plan, HNF-1900, Rev. 0, Lockheed Martin Hanford Corporation, Richland, Washington. 
HNF-3045

Revision 0

This page intentionally left blank. 
HNF-3045

Revision 0

\section{APPENDIX A}

\section{DOCUMENT CONTROL CHECKSHEET}

\section{Subproject:}

Subproject Bngineer/Gatekeeper:

Summary of Required Change:

A. REQUIREMENTS CHANGES

1. Forms completed:

Requirements Database Change Request

Coversheet (for DCS docs only)

Engineering Data Transmittal

Distribution List

Engineering Change Notice (for DCS docs only)

Record of Revision (for DCS docs only)

2. Submitted for approval to:

3. Approved by:

Gatekeeper

Change Control Board (By Gatekeeper)

Project Manager (By Gatekeeper)

4. Submitted to RDD-100 Administrator by Gatekeeper

5. Changes Incorporated Into RDD-100 By Administrator

6. RDD-100 Documents Returned by Gatekeeper

7. Documents Submitted to Working File Administrator

B. DOCUMENT CHANGES OR SUBMITTALS

1. Document Identification Number from DCSC

2. Identify and mark sensitivities

3. Forms:

Engineering Change Notice

Record of Revision

Engineering Data Transmittal

Distribution List (Include sensitivity information as necessary)

Release Authorization Form

Limited Distribution Cover Sheet (sensitive information only)

4. Submitted for approval to:

5. Approved by:

Gatekeeper

W-519 Project Manager

Change Control Board (By Gatekeeper)

6. Documents Submitted to Working File Administrator 


\section{HNF-3045}

Revision 0

This page intentionally left blank. 
HNF-3045

Revision 0

APPENDIX B

\section{SAMPLE PROJECT RECORDS INDEX SUBJECTS}

Note: This is a sample of the typical subject listings in the Project Records Index. For a complete and updated listing, contact the Project Files Custodian.

PROJECT RECORDS INDEX/PACKAGE ACCEPTANCE RECORD ADMINISTRATIVE

CORRESPONDENCE

- $\mathrm{A} / \mathrm{E}$ Correspondence

- Letter of Instruction

- Letters/Memos

- DSIs/CC:Mail

- CC Correspondence

- Letter of Instruction

- Letters/Memos

- DSIs/CC:Mail

- OC Correspondence

- Letter of Instruction

- Letters/Memos

- DSIs/CC:Mail

- RL Correspondence

- Letter of Instruction

- Letters/memos

- DSIs/CC:Mail

- Other Correspondence

TRANSMITTALS

TELEPHONE RECORDS

MEETING MINUTES

- Technical Review Boards

- Key Reviews

- Management Review Boards

- Critical decisions

TRIP/CONFERENCE REPORTS

PROGRESS REPORTS/STATUS REPORTS (monthly, quarterly, weekly, daily)

REVIEW COMMENTS/DATA

PHOTOGRAPHS/VIDEOS

KEY DECISIONS/MILESTONES

- Project Validation

OTHER ADMINISTRATIVE DOCUMENTS

- Presentations

- Task Orders 
HNF-3045

Revision 0

PLANNING (INPUTS)

ENGINEERING STUDY/LETTER REPORTS

SUPPLEMENTAL DESIGN REQUIREMENTS DOCUMENT

CONCEPTUAL DESIGN REPORTS

FUNCTIONAL DESIGN AND DESIGN REQUIREMENTS

SITE EVALUATION

MANAGEMENT PLANS

PROJECT PLAN

WORK PLANS

SCHEDULES

STATEMENT OF WORK

PROJECT START-UP CHECKLIST

VALUE ENGINEERING

TECHNICAL DATA CHECKLIST

PLANT FORCES WORK REVIEW

OTHER PLANNING DOCUMENTS

DESIGN (OUTPUTS)

DRAWINGS

CALCULATIONS

SPECIFICATIONS

- CONSTRUCTION

- PROCUREMENT

- GENERAL

DESIGN VERIFICATION

OTHER DESIGN DOCUMENTS

INTERFACE CONTROL

FINANCIAL

PROJECT AUTHORIZATION/MODIFICATION

WORK ORDERS

CHANGE REQUESTS

ENGINEERING CONSTRUCTION CHANGE

ESTIMATES

JUSTIFICATION FOR NEW START/MISSION NEED

PURCHASE ORDERS

- Purchase Requisitions

- Material Requisitions

OTHER FINANCIAL DOCUMENTS

\section{SAFETY}

PRELIMINARY SAFETY EVALUATION

FIRE HAZARDS/PROTECTION/SAFETY CLASSIFICATION

PRELIMINARY/FINAL SAFETY ANALYSIS REPORT 
HNF-3045

Revision 0

PRE-JOB SAFETY PLANNING/JOB SAFETY ANALYSIS

OTHER SAFETY DOCUMENTS

NUCLEAR REGULATORY COMMISSION DOCUMENTATION

ALARA

UNREVIEWED SAFETY QUESTIONS

ENVIRONMENTAL

ASSESSMENTS/EVALUATIONS/ANALYSES

IMPACT STATEMENT

RESOURCES REVIEWS

HEHF REPORTS

OTHER ENVIRONMENTAL DOCUMENTATION

QUALITY ASSURANCE

QUALITY ASSURANCE PLANS

ASSESSMENTS/SURVEILLANCES

OTHER QUALITY ASSURANCE DOCUMENTS

CONSTRUCTION (OUTPUTS)

PERMITS

SURVEY DATA

NOTICE OF CONSTRUCTION

CHANGE NOTICES

PROCESS/WORK CONTROL PACKAGES

SUBMITTALS/VENDOR INFORMATION

RECORD OF FIELD WALKDOWNS

CONTRACT DOCUMENTS

OTHER CONSTRUCTION DOCUMENTS

SUPPLIER/SUBCONTRACTOR DISPOSITION REQUESTS

\section{QUALITY CONTROL}

TEST PROCEDURES/ REPORTS

INSPECTION PLANS

SITEWORK RECORDS

- Concrete Records

- Mechanical Records

- Electrical Records

PRESSURE TEST CERTIFICATIONS

INSPECTION REPORTS

NONCONFORMANCE REPORTS

WELD RECORDS/WELD MAPS

PUNCHLISTS/DEFICIENCY REPORTS

MEASURING AND TEST EQUIPMENT USE RECORD

CRITICAL LIFT PROCEDURES

DRILL LOGS 
HNF-3045

Revision 0

GENERAL INSPECTION LIST/SURVEILLANCE REPORTS

OTHER QUALITY CONTROL RECORDS

\section{CLOSEOUT}

ENGINEERING FINAL DESIGN CHECKLIST

WORK ACCEPTANCE

OFFICIAL ACCEPTANCE OF CONSTRUCTION

LESSONS LEARNED

CONSTRUCTION COMPLETION AND COST CLOSING STATEMENT (4Cs)

OTHER CLOSEOUT DOCUMENTS

OPERATIONS

OPERATION TEST PROCEDURES/REPORTS

ASSESSMENTS

PLANS

EQUIPMENT TESTING

SURVEILLANCES

READINESS CHECKLIST

SAFETY 
HNF-3045

Revision 0

\section{APPENDIX C}

TANK WASTE REMEDIATION SYSTEM PRIVATIZATION INFRASTRUCTURE REQUIREMENTS DATABASE CHANGE REQUEST FORM

- $\quad$ Requirements Database Change Request (DCR Form)

- Samples of Backup Materials 
HNF-3045

Revision 0

This page intentionally left blank. 
HNF-3045

Revision 0

\section{APPENDIX C}

\section{TANK WASTE REMEDIATION SYSTEM PRIVATIZATION INFRASTRUCTURE REQUIREMENTS DATABASE CHANGE REQUEST}

DCR number: 000

EFFECTED DOCUMENT (FRD, PDC, WRS Spec, etc):

DATE of .mdb/.im file:

TODAY'S DATE: 12/17/96 CHANGE PROPOSED BY (your name):_M. Leonard ORGANIZATIONS AFFECTED (who you think will be affected by change):

ACTR C-106 Retrieval Closure Basis

Project Lead OTHER(specify)

HSTB / TWRS-SE (Date of affected version)

\section{SUMMARY OF PROPOSED CHANGE:}

Example data input format for System Requirements. Also gives examples on how to change data already in database (C-106 Retrieval Demonstration System Component)

WHY IS THE CHANGE NEEDED (benefit of change):

Communicate to HTI Leads and Team members how to change to the database.

SPECIFIC CHANGES TO DOCUMENT (as needed, provide attachment of affected pages with pen and ink or similar markups clearly showing proposed changes):

See Attached

TEAM LEAD REVIEW (others as needed):

\begin{tabular}{|l|l|l|l|}
\hline & & & \\
\hline J.A. Yount, ACTR & Date & L.B. McDaniel, C-106 Ret. & Date \\
\hline \hline & & & \\
\hline E.A. Fredenburg, Closure & Date & P.S. Schaus, SE Lead & Date \\
\hline \hline & & & \\
\hline & Date & F\&R database & Date \\
\hline
\end{tabular}

ADMINISTRATIVE

\begin{tabular}{|l|l|l|l|}
\hline & & & \\
\hline & Date & Database Admin. & Date \\
\hline & & & \\
\hline Incorporated by: & Date & & Date \\
\hline
\end{tabular}

CHANGE IMPLEMENTED: (Requestor) 
HNF-3045

Revision 0

This page intentionally left blank.

C-4 
HNF-3045

Revision 0

\section{EXAMPLE SYSTEM REQUIREMENT DATA INPUT FORM ATTRIBUTES AND RELATIONSHUPS}

Element Type: System Requirement

Element Name: "Enter Name of SR IAW TWRS RDD-100 Users's Guide (Section 3.2)" Element Number:

\section{ATTRIBUTES}

creator: «RDD Auto entry"

creation Date: «RDD Auto entry»

modification Date: «RDD Auto entry»

modification Time: «RDD Auto entry»

description: "Enter Requirement text"

requirement Type: «null (if Constraint), Performance, Functional, Design Constraint»

title: «Give Requirement Title. For Derived requirements this is the string that prints as the Spec. Section title"

project Unique ID: «For Constraints, TWRS; For Derived Requirements, HTI or null»

\section{RELATIONS}

Relation: categorized_by

Related Type: Category

Related Number:

Related Name: "Constraint or Derived"

Relation: "documented_by or incorporated_by"

Related Type: "Source or System Requirement"

Related Number:

Related Name: 


\section{Conditional Relationships}

Relation: raises

Related Type: Critical Issue .

Related Number:

Related Name:

Relation: resulted_from

Related Type: Decision

Related Number:

Related Name:

If Category = "Derived", then:

Relation: traces_to

Related Type: "Component or Time Function"

Related Number:

Related Name:

Relation: verified_by

Related Type: Verification Requirement

Related Number:

Related Name: 
HNF-3045

Revision 0

\section{Example Component Change}

Element Type: Component

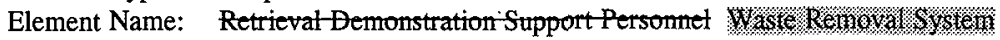

Element Number: 2.1

\section{ATTRIBUTES}

creator: Hanford Tanks Initiative

creationDate: $08 / 29 / 96$

modificationDate: $09 / 26 / 96$

modificationTime: $14: 44: 17$

Description: Retrievat operations support personnel that set-up,

operate, disassemble and maintain the waste retrieval system being tested.

This atso inctudes any supplies (spares) and tool kits (wrenches, serewtrivers, multimeters, ete.) required to support the related activities.

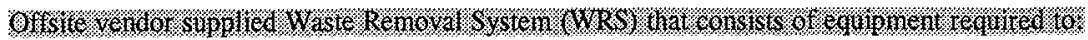

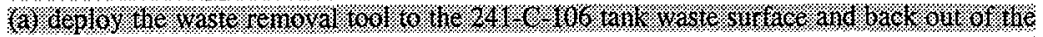

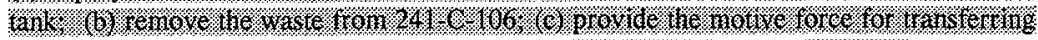

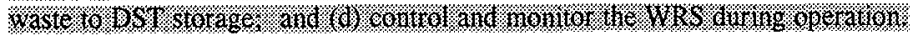

componentType: System Segment

status: Pending

approvedBy:

\section{RELATIONS}

Relation: traced_from

Related Type: SystemRequirement

Related Number:

Related Name: DOE 5480.11A, 5480.10 ; WHC-CM-4-11, Appendix 7-B

Relation: traced_from

Related Type: SystemRequirement

Related Number:

Related Name: $\quad$ DOE Order 5480.11 9.j(1)(d); WHC-CM-4-9, 4-11; 
HNF-3045

Revision 0

\section{ORNL/TM-10864}

Relation: traced_from

Related Type: SystemRequirement

Related Number:

Related Name: DOE Order 5480.11, W-340-0 C1, F\&A ISU1

Relation: traced_from

Related Type: SystemRequirement

Related Number:

Related Name: $\quad$ OSD-T-151-00013.3

Relation: traced_from

Related Type: SystemRequirement

Related Number:

Related Name: W-340-0 C1, ISU1, WHC-EP-0352

Relation: resulted_from

Related Type: Decision

Related Number:

Related Name: HTI Tank Farm Retrieval Architecture Enabling Assumption

Relation: owned_by

Related Type: Engineer

Related Number: (ghost)

Related Name: Hanford Tanks Initiative

Relation: built_in

Related Type: Component

Related Number: 2.0

Related Name: Tank Farm Retrieval Demonstration System

Relation: performs

Related Type: TimeFunction

Related Number: 1.2 .3 .8 :

Related Name: Đeativate Tank Beploy.Waste Remoxt Systen

Relation: performs

Related Type: TimeFunction

Related Number: $1 \cdot 2.3 .3$ 6

Related Name: Instatt WRS Renione Waste furm 241 I . 106

Relation: performs

Related Type: TimeFunction

Related Number: 1.2.3.107 
HNF-3045

Revision 0

Related Name: Maintain-Retrieval System Transfer Waste to DST Storage

Relation: performs

Related Type: TimeFunction

Related Number: 1.2.3.5 9

Related Name: Operate Retrieval-System Control and Monitor the WRS 
HNF-3045

Revision 0

This page intentionally left blank. 
HNF-3045

Revision 0

\section{APPENDIX D}

\section{SENSITIVE INFORMATION CONTROL INSTRUCTIONS AND FORMS}

- Supporting Documentation Cover Sheet Completion Instructions

- Sample Forms

- Limited Distribution Only: Not for Public Release

- Approved for Public Release 
HNF-3045

Revision 0

This page intentionally left blank.

D-2 


\section{SUPPORTING DOCUMENT COVER SHEET COMPLETION INSTRUCTIONS}

The Department of Energy and its contractors are committed to free and open, public access to information. However, release of information must comply with the laws that protect the privacy of the public, the legal rights of industry, and safeguard the national security.

This Guidance/Instruction will assist you in determining if your document can be given public release; providing details on proper handling of trademarks and copyrighted information. Also included are definitions of specific types of limited use information NOT for public release.

Documents that will be listed at OSTI must include the Unclassified Category (UC-) number and Budget and Reporting (B\&R) Code. Assistance is provided on HLAN Soft Reporting "Document Clearance/Availability" for determining the applicable UC number and B\&R Code. For further guidance, see WHC-CM-3-4 (on HLAN Hanford Information) or contact your document clearance office, listed on HLAN phone directory.

\section{DEFINITIONS}

\section{APPLIED TECHNOLOGY (NOT for public release)}

Information, designated as Applied Technology by DOE/HQ, pertaining to engineering, development, design, construction, operation, or technology advances in specific facilities or programs (e.g., FFTF or SP-100). Hanford projects which may contain or reference Applied Technology are:

- FFTF (Fast Flux Text Facility)

- SP-100 (Space Reactor Power Systems)

- EBR II (Experimental Breeder Reactor II at Idaho)

- TREAT (Reactor Fuels Test Facility at Idaho)

- Liquid Metal Fast Breeder Reactors (LMFBR)

\section{BUDGET \& REPORTING (B\&R) CODE}

Code indicating the funding source for specified work. NOTE: Budget \& Reporting (B\&R) codes are available on HLAN Soft Reporting "Document Clearance/Availability Status." Select submenu "UC Categories and B\&R Number Information." Press F10, enter "FDST119R" and the applicable TCPN, and the applicable B\&R number will be displayed.

\section{BUSINESS SENSITIVE INFORMATION (NOT for public release)}

Information disclosed in confidence and sensitive in content, and marked by the originator with a restrictive marking such as "Business Sensitive" or "Company Sensitive."

\section{CLASSIFIED INFORMATION (NOT for public release)}

Restricted Data" (RD), "Formerly Restricted Data" (FRD), or "National Security 
HNF-3045

Revision 0

Information" (NSI) requiring protection against unauthorized disclosure in the interest of national security.

\section{COPYRIGHTED INFORMATION (requires permission)}

Violation of the copyright law occurs when the copyrighted work is copied without the express permission of the copyright holder. Although displaying the copyright symbol is NOT required, often copyrighted information is marked with the Copyright symbol ( $\left.{ }^{(}\right)$.

Permission (using WEF220) from the copyright holder is required BEFORE the information can be reprinted. Acknowledgement of permission is also required in the document.

\section{EXPORT CONTROLLED INFORMATION (ECI) (NOT for public release)}

Export Controlled Information (ECI) is unclassified information which, if exported by a private corporation, would require an export license from the Department of Commerce, Nuclear Regulatory Commission, or Department of State (DOS), or an authorization from the Secretary of Energy. ECI, if distributed to other nations, could adversely effect the nuclear nonproliferation objectives, national security, or economic security of the United States of America. ECI includes scientific and technical information related to nuclear weapons design and production, special nuclear material production, and technologies of the nuclear fuel cycle.

Hanford topics that may contain ECI are:

- Reactor design/construction/modification

- Resolutions of reactor flaws or malfunctions

- Diagrams of reactor design, construction, function

- Nuclear fuel cycle; fuels/loading improvements

- Nuclear Weapons technology, design, characteristics, production

- Characteristics and production of Special Nuclear Material (SNM)

\section{LIMITED DISCLOSURE INFORMATION (NOT for public release)}

Limited use information (e.g., Applied Technology information) that may be provided to specific foreign nations, in accordance with an international exchange agreement. Limited disclosure information must be marked and distribution must be controlled, in accordance with the agreement.

\section{LIMITED USE INEORMATION}

Categories of information that are legally restricted from public release. Limited use information requires markings to identify and indicate limited (non-public) distribution.

\section{PATENTABLE SUBJECT MATTER (NOT for public release)}

Any new and useful method, process, machine, article, manufacture of matter, or composition of matter; or any new and useful improvement thereof, including novel and potentially important commercial industrial process or machine invention embodiments incorporating software or firmware computer program components. Potentially 
patentable subject matter includes a patentable invention for which an invention disclosure has not been deactivated or for which a patent application has not been filed.

\section{PERSONAL/PRIVATE INFORMATION (NOT for public release)}

Individually identifiable information including, but not limited to, information about education, financial transactions, medical or exposure history, family, criminal or employment history, and information that contains an individual's age, home address or telephone number, payroll number, Social Security number, religion, symbol, or other such identifying particulars assigned to the individual, such as a fingerprint, voiceprint, or photograph.

\section{PREDECISIONAL INFORMATION (requires DOE/PHMC approval)}

Information compiled before the act of making or coming to a judgement, determination, or conclusion, or information on which a decision eventually may be based.

Predecisional information may include advisory opinions, alternative possibilities, potential recommendations, or deliberations that will constitute the basis for a judgement. Certain predecisional information is privileged under the Freedom of Information Act (FOIA) and may not be released to a requestor until after the final decision has been rendered. Other predecisional information, such as Draft Environmental Impact Statements, must be submitted to the public for comment, so that the final decision incorporates public input.

\section{PROCUREMENT SENSITIVE INFORMATION (requires DOE/PHMC approval)}

Information relating to a planned or pending procurement. (For further information contact Contracts Administration and Procurement.)

\section{PROPRIETARY INFORMATION (NOT for public release)}

Information, marked as "Proprietary Information" by the originator, which embodies trade secrets developed at private expense outside of the PHMC/DOE contract. It is commercial or financial information which is privileged or confidential under FOIA.

\section{PROTECTED CRADA INFORMATION (NOT for public release)}

Information that is marked "Protected CRADA Information" by a party to the Cooperative Research And Development Agreement (CRADA), and that would have been "Proprietary" information, had it been obtained from a non-federal entity. The "Protected CRADA Information" legend will also include the specific assigned expiration date (not to exceed five years) for protecting the information from public release.

\section{TRADEMARK (Identify owner of trademark in document)}

Any word, name, symbol, or device, or any combination thereof, adopted and used by a manufacturer or merchant to identify goods and distinguish them from those manufactured or sold by others. The author is responsible for identifying trademarks mentioned in the document, indicating the owner of the trademark, (e.g., Teflon is a trademark of DuPont Nemours, Inc.). Trademarks can be called out in any of the following ways: 
- With footnote at bottom of page

- In text directly following the trademark

- On "trademark sheet" at beginning of document

- With electronic "link" or "hot button"

\section{UNCLASSIEIED CATEGORY (UC)}

Distribution categories for unclassified information transmitted to or listed by DOE's Office of Scientific and Technical Information (OSTI). HLAN Soft Reporting "Document Clearance/Availability Status" submenu "UC Categories and B\&R Information" provides UC-numbers and descriptive definitions commonly related to Hanford.

\section{UNCLASSIEIED CONTROLLED NUCLEAR INFORMATION (UCNI) (NOT for public release)}

Nuclear information that is unclassified, but that requires controlled distribution, because it could significantly assist in any of the following:

- Theft of Special Nuclear Materials (SNM).

- Nuclear sabotage that may endanger the environment, or the public health, safety, or national security.

- Clandestine production of nuclear weapons. 
Release Instructions (RI) No Return Receipt is used for revisions to documents that have a controlled distribution when the author determines written verification is not required.

Release Instructions (RI) Return Receipt Required is used for documents that have a controlled distribution and the author requires written verification that the document has been received.

The initial distribution list is submitted by using the Distribution Sheet. All copyholders will receive revisions.

Business Sensitive records are not scanned, only indexed for tracking purposes into RMIS, Unclassified Document Control, Phyliss Jones, Rosemary Magnuson, performs the distribution process from the Federal Building. 
HNF-3045

Revision 0

HNF, Rev.

\section{TITLE:}

Author's Mane:

Author's Company: , Richland, WA 99352

U.S. Department of Energy Contract DE-AC06-96RL13200

EDT/ECN: \#

Org Code:

UC: 2030

Charge Code:

B\&R Code:

Total Pages:

Type of LIMITED USE Information: (for example: "PROPRIETARY"

Key Words:

Abstract:

Printed in the United States of Americe. To obtain copies of this document, contsct: Doeument Control services, P.O. Box 950, Moilstop 16-08, Richland HA 99352, Phone (509) 372-2420; Fax (509) 376-4989.

\section{LIMITED DISTRIBUTION ONLY; NOT FOR PUBLIC RELEASE}




\section{INFORMATION CLEARANCE FORM}

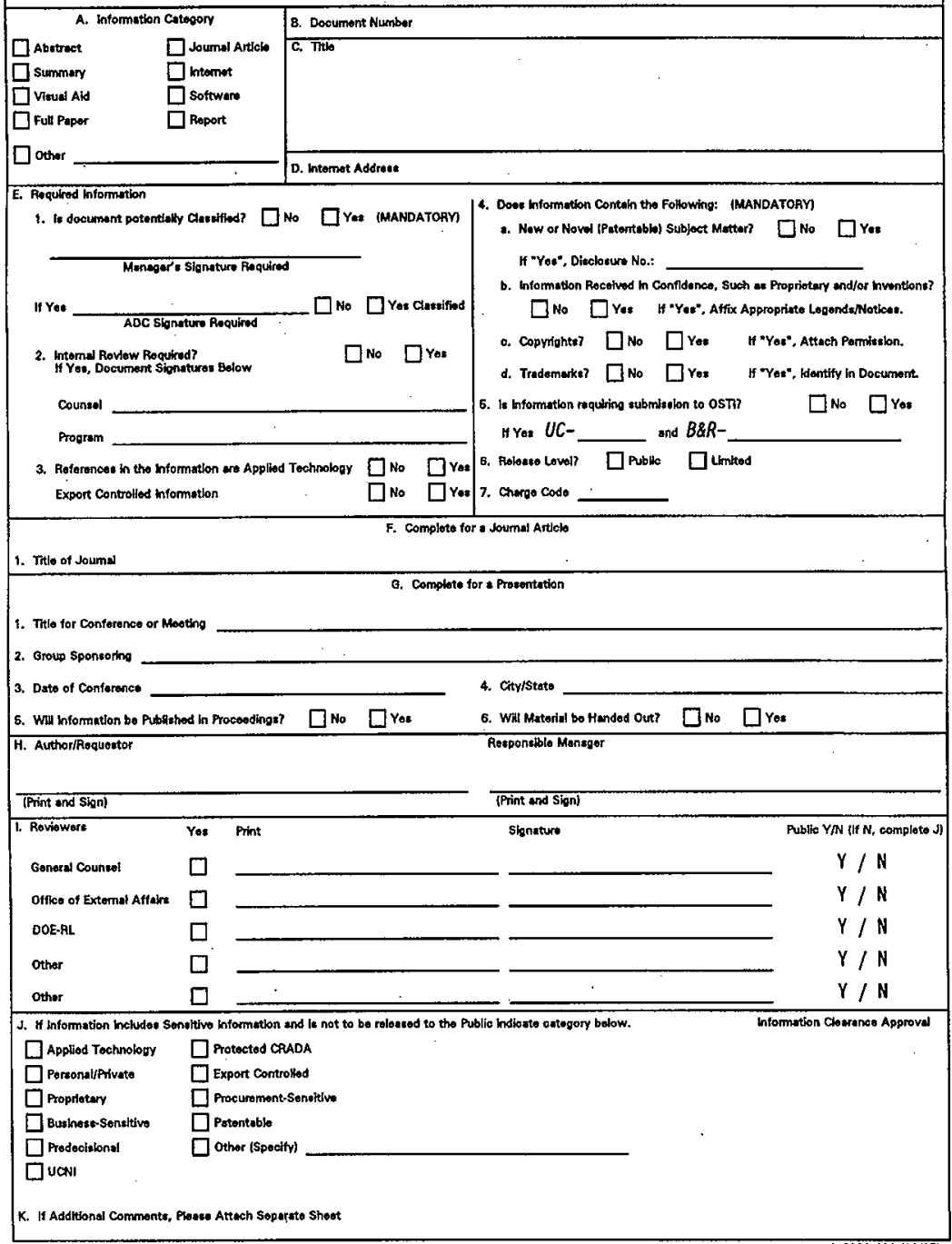


HNF-3045

Revision 0

HNF, Rev.

\section{TITLE:}

Author(s) name:

Author's Company:

, Richland, WA 99352

U.S. Department of Energy Contract DE-AC06-96RL.13200

EDT/ECN: \#

Org Code:

B\&R Code:

UC:

Charge Code:

Total Pages:

Key Words:

Abstract:

TRADEMARK DISCLAIMER, Reference herein to any specific commercial product, process, or service by trade name, trademark, manufacturer, or otherwise, does not necessarily constitute or imply its endorsement, reconmendation, or favoring by the United states Government or any agency thereof or its contractors or subcontractors.

Printed in the United States of America. To obtain copies of this document, contact: Document Control Services, P.D. Box 950, Mailstop H6-08, Richland WA 99352, Phone (509) 372-2420; Fax $(509) 376-4989$.

\section{Approved for Public Release}

A- 6400-073 (01/97) GEF32? 


\section{DISTRIBUTION SHEET}

\begin{tabular}{|c|c|c|c|c|c|}
\hline \multirow{2}{*}{$\begin{array}{l}\text { To } \\
\text { Distribution }\end{array}$} & \multirow{2}{*}{\multicolumn{3}{|c|}{$\begin{array}{l}\text { From } \\
\text { R. W. Root }\end{array}$}} & \multicolumn{2}{|l|}{ Page 1 of 1} \\
\hline & & & & \multicolumn{2}{|c|}{ Date $9 / 24 / 98$} \\
\hline \multirow{2}{*}{\multicolumn{4}{|c|}{$\begin{array}{l}\text { Project Title/Work Order } \\
\text { Tank Waste Remediation Ssytem Privatization Infrastructure } \\
\text { Program Requirements and Document Management Process Guide, } \\
\text { HNF }-3045 \text {, Rev. 0 }\end{array}$}} & \multirow{2}{*}{\multicolumn{2}{|c|}{$\begin{array}{ll}\text { EDT No. } & 625348 \\
\text { ECN No. } & \text { N/A }\end{array}$}} \\
\hline & & & & & \\
\hline \multicolumn{2}{|l|}{ Name } & $\begin{array}{c}\text { Text } \\
\text { With All } \\
\text { Attach. }\end{array}$ & Text Only & $\begin{array}{l}\text { Attach./ } \\
\text { Appendix } \\
\text { Only }\end{array}$ & $\begin{array}{c}\text { EDT/ECN } \\
\text { Only }\end{array}$ \\
\hline $\begin{array}{l}\text { Central Files } \\
\text { DIMC } \\
\text { DOE Reading Room } \\
\text { HTI Project File (2) }\end{array}$ & $\begin{array}{l}\text { B1- } 07 \\
\text { H6-15 } \\
\text { A1-65 } \\
\text { H6-08 }\end{array}$ & $\begin{array}{l}x \\
x \\
x \\
x\end{array}$ & & & \\
\hline $\begin{array}{l}\text { S. K. Baker } \\
\text { D. L. Banning } \\
\text { G. A. Barnes } \\
\text { D. L. Becker } \\
\text { E. J. Berglin } \\
\text { J. W. Bloom } \\
\text { L. E. Borneman } \\
\text { H. L. Boston } \\
\text { W. S. Callaway III } \\
\text { D. R. E17ingson } \\
\text { V. F. Fitzpatrick } \\
\text { P. W. Gibbons } \\
\text { D. B. Hagmann } \\
\text { J. J. Huston } \\
\text { D. F. Iwatate } \\
\text { S. A. Krieg } \\
\text { T. H. May } \\
\text { A. B. McDanie } \\
\text { A. F. Noonan } \\
\text { E. M. Northrop } \\
\text { S. M. O'Toole } \\
\text { R. J. Parazin (2) } \\
\text { L. G. Peck } \\
\text { T. E. Rainey } \\
\text { F. R. Reich } \\
\text { R. W. Root (Informatics) } \\
\text { H. Rossi (TRW) } \\
\text { P. S. Schaus } \\
\text { R. E. Schrempf } \\
\text { C. L. Weber (Informatics) } \\
\text { J. A. Yount } \\
\text { G. R. Porter }\end{array}$ & 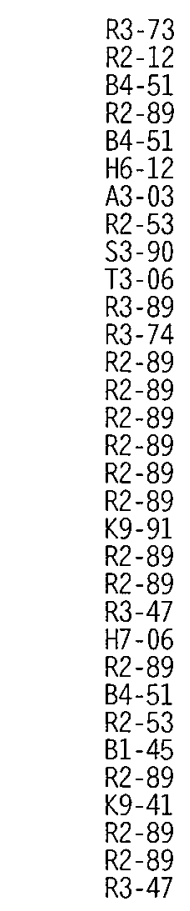 & $\begin{array}{l}x \\
x \\
x \\
x \\
x \\
x \\
x \\
x \\
x \\
x \\
x \\
x \\
x \\
x \\
x \\
x \\
x \\
x \\
x \\
x \\
x \\
x \\
x \\
x \\
x \\
x \\
x \\
x \\
x \\
x \\
x \\
x \\
x \\
x \\
x\end{array}$ & & & \\
\hline
\end{tabular}

